\title{
Law and theology in the Covenant Code
}

M J Oosthuizen

\section{ABSTRACT}

The paper considers the relationship between law and theology within the Covenant Code. The first part of the discussion reviews the influence of the "divine law" hypotheses of Alt and Noth, on contemporary scholarship. Particular reference is made to the consequences which Weinfeld draws from this hypothesis, for his view of the secularisation process in the Deuteronomic code. Subsequently, Halbe's theory concerning the development of Israelite law from a body of divine Privilegrecht in Exodus 34:1126, is discussed. Despite the methodological rigour of Halbe's redactional analysis, the theory that the divine will serve as the primary catalyst for the development of ancient Israelite law is rejected. In accord with the recent redactional analyses of the Covenant Code by Osumi, Crüsemann, Schwienhorst-Schonberger and Otto, it is accepted that the integration of law and theology represents a secondary stage of the code's compositional development. The major part of the paper investigates the quite distinct reconstructions of the theological validation of law by these recent studies.

\section{INTRODUCTORY COMMENTS}

Towards the end of his analysis of the redactional shaping of the Covenant Code, Otto makes the crucial observation that "Die Rechtsgeschichte Israels ist als Geschichte der Integration des Rechts in den Gotteswillen zu schreiben"1. These remarks seem fairly self-evident. There is, after all, hardly any question that ancient Israelite law derived its ultimate authority from Yahweh. In fact, many scholars have worked from what may be referred to as a "divine law" hypothesis, which posits an originary and fundamental connection between Yahweh and the development of biblical law. The significance of Otto's study is that it exemplifies a growing realisation that the connection between law and theology is by no means as direct or obvious as has generally been assumed. Thus Crüsemann asserts that early Israelite law was in no sense divine law (Gottesrecht), and his view is shared and explicitly motivated by a number of significant recent German works which all deal with the problem of the redactional formation of the Covenant Code - i.e. Otto, Schwienhorst-Schönberger and Osumi².

The purpose of the present paper is to explore the implications of these recent redactional studies for understanding the relationship between 
law and theology within the Covenant Code. In particular, it will be asked how - if at all - the diverse redactional constructions which they propose, can illuminate socio-religious processes which may have led to the increasing integration of law within the will of Yahweh. While the discussion is specifically concerned with the Covenant Code, it is clear that a fresh assessment of the social and theological forces which were at work in its formation, has wider ramifications for the analysis of biblical law. To name only one, but salient, point. It is well known that Weinfeld, whose opinion will be dealt with in more detail in the next section, has proposed that the Deuteronomic Code represents the increasing desacralisation ad secularisation of Israelite law over against the earlier Covenant and (sic!) Holiness Codes. In contrast, this paper at least suggests that the Deuteronomic Code stands in the continuum of the process of theological legitimisation which was at work in the Covenant Code. It is thus quite fallacious to argue that Israelite law is characterised by a process of growing secularisation.

The analyses of Otto, Schwienhorst-Schönberger, Osumi and Crüsemann, must be placed against the relief of earlier and current research trends. Accordingly, the first part of the paper will refer to Alt and Noth's appraisal of apodictic law, as a basis for a critique of various attempts to advocate a "divine law" approach. Subsequently, the work of Halbe, which has laid the basis for all further redactional analysis of the Covenant Code, will briefly be reviewed ${ }^{3}$. The more recent German studies all adopt a more or less critical stance towards his thesis that the redactional formation of the Covenant Code can be traced to an original layer of divine Privilegrecht.

A final introductory comment on the paper's primary engagement with German studies is in order. Various recent works on the Covenant Code adopt methodological positions, or engage a line of enquiry, which afford no perspective on the problem of law and theology. Thus, Westbrook's option to view biblical law as merely a part of the Ancient Near Eastern law, and to eschew questions of internal redactional development, eliminates the possibility of delineating specific theological characteristics within the Covenant Code. If biblical law codes do not represent autarchic systems, but are solely components of a coherent and largely static body of Ancient Near Eastern material, then it is methodological impossible to assume that the contents of the Covenant Code could be influenced by distinctive developments within Israelite religion ${ }^{4}$. Carmichael relates the Mishpatim (Ex 20:23-23:19) to the literary activity of Deuteronomic scribal circles, who created the laws on the basis of the 
Jacob-Joseph and Exodus narratives, following models from Ancient Near Eastern codes. His view deliberately rejects an investigation of historical processes which could have facilitated the integration of legal material under Yahweh's patronages. Finally, Marshall pursues an anthropological approach which, while highly suggestive, does not address the question of the relationship between law and religious ideology6.

\section{THE DEVELOPMENT OF A “DIVINE LAW" HYPOTHESIS UNDER THE INFLUENCE OF ALT AND NOTH}

Alt consolidated Jepsen's distinction between four bodies of legal corpora within the Covenant Code?, into the two formal categories of apodictic and casuistic law. As is well-known, he identified three series of ten or twelve apodictic stipulations in the Decalogue (Ex 20), the list of curses in Deuteronomy $27: 15-26$, and a third list consisting of various prohibitions from the Covenant and Holiness codes $\mathbf{8}$. Typifying these injunctions as unique to Israel, he could claim that they were rooted in the covenant relationship with Yahweh, and that their seven-yearly proclamation at the Feast of Tabernacles formed the basis for the covenant renewal'. In distinction from the casuistic laws, therefore, the apodictic commands point to the incorporation of ius, fas and ethos within the divine will, as a fundamental and pristine aspect of Israelite religion. The clash between the apodictic and casuistic law, which is reflected in various passages in the Covenant Code, provided the impetus for the gradual absorption of various areas of civil or "secular" law within the sphere of Yahweh's sovereignty10.

Subsequently, Noth's identification of the amphictyony as the institutional sphere in which the apodictic laws were applied and preserved by the minor judges (cf. Judges 10:1-5; 12:7-15), significantly reinforced Alt's theory'1. While casuistic law belongs to the normal judicial activity at the gate ${ }^{12}$, the divine law was reserved for special cultic centres and ceremonies (specifically the Feast of Tabernacles) where Israel was confronted with the covenant demands of Yahweh ${ }^{13}$. Weiser could even claim that the reference to Samuel's judicial activity in 1 Samuel 7:15-17 does not present Deuteronomistic redaction, but rather preserves a historical tradition concerning his application of the divine law, in continuity with the minor judges ${ }^{14}$. The special status of apodictic law assumed a further dimension which was never intended by Alt, when it was interpreted in a Barthian sense as the product of divine revelation's.

The theses which were developed by Alt and Noth have of course been submitted to substantial critique. There is general consensus that 
apodictic law is not specifically Israelite ${ }^{16}$. Within the Gattung of "apodictic law", Gerstenberger has convincingly distinguished between apodictic prohibitions and commands which express normative stipulations, and those which belong with the casuistic laws to the sphere of justice in the gate ${ }^{17}$. The dismissal of Noth's amphictyony hypothesis has also refuted the supposed institutional setting of apodictic law ${ }^{18}$. While the issue of the type of judicial activity - if any - which can be associated with the minor judges and a figure such as Samuel is disputed ${ }^{19}$, it is at least clear that they could not have fulfilled any special role in the administration of the so-called divine law. Finally, recent studies have substantially modified the rather simplistic thesis concerning "justice at the gate", in favour of a more intricate appreciation of the social spheres in which the casuistic law developed in especially the premonarchic period ${ }^{20}$.

More pertinent to the specific interest of the present discussion, however, is that such modifications of Alt and Noth's views have not necessarily engendered any greater clarity concerning the relation between law and theology. It is notable that Gerstenberger could already argue that within the body of apodictic normative stipulations, only the sacral provisions (fas) enjoy a primary link with the covenant. The connection between the larger group of social normative stipulations (ethos) and the covenant renewal ceremonies at the Feast of Tabernacles is a secondary development, which followed their primary association with the Israelite clan ethos ${ }^{21}$. Gerstenberger's analysis suggests that the process which led to the incorporation of ius, fas and ethos within the divine will is far more complex than Alt assumed.

Nevertheless, various scholars have continued to posit an originary and germinal link between the Deity and biblical law. In some cases the argument for such an incipient connection seems to rest on sheer assumption - for example in assertions concerning God as the "fountainhead of the law" 22 , or as the "source and formulator of the law"23. In Paul's case, the theocentric frame sections of the Sinai periscope (Ex 19:3-6, 23:20-33) provide a theological motivation which reinforces the status of the Decalogue (Ex 20:1-17) and the Book of the Covenant (Ex 20:22-23:19) as divine law ${ }^{24}$. These scholars display little interest in internal textual indicators within a corpus such as the Covenant Code, as to the historical processes which led to the incorporation of ius, fas and ethos under the patronage of Yahweh25. What is clear, is that such divine law theses provide a springboard for various claims concerning characteristic values and features which are attributed to the legal corpora of the Bible ${ }^{26}$. The clarificatory perspective which is afforded by some other scholars who 
work with a keener historical awareness, is hardly more illuminating. Both Donner and Boecker refer to the gradual process through which the diverse material which is contained in collections such as the Covenant Code was subsumed under the divine will. Yet, both of them are content to merely affirm the fundamental conviction that all law stems from Yahweh, as the catalyst which provided the integrative force for the collation of the laws from the time of the pre-monarchic period 27 .

Because of the widespread influence of his views on the Deuteronomic laws, one final example of a fundamental divine law hypothesis deserves more extensive comment. I refer to Weinfeld's theory concerning the seminal role of the original short form of the Decalogue in Exodus 20, which he regards as the foundation document of the Israelite community, on the development of Israelite law28. According to him, the decalogical stipulations, which established the primary covenant relationship with Yahweh, provided the impetus for the further elaboration of the judicial tradition which is reflected in various collections within the Hebrew Bible. Despite his postulation of a different institutional setting (the Shebuot Festival) for the yearly proclamation of the Decalogue 29 , Weinfeld's theory presents a logical continuation of the views of Alt, and other scholars who accept the intrinsic nature of Israelite law as rooted in the will of Yahweh.

The decisive aspect of Weinfeld's thesis becomes clear when he turns to the description of the "secularisation" process in the Deuteronomic Code ${ }^{30}$. Various statements in his discussion suggest that he understands the development of biblical law along the lines of the evolutionary scheme which the influential jurist Maine proposed during the nineteenth century ${ }^{31}$. Now, it is well known that legal scholars and anthropologists have refuted Maine's notion that primitive law necessarily emerged as a mixture of religious, moral and legal precepts which had a divine origin, while later stages of mental progress were supposedly characterised by the progressive severance of law from the authenticating sphere of religion ${ }^{32}$. Purely in terms of legal anthropology, therefore, Weinfeld's hypothesis enjoys no indisputable support. His attempt to support the "secularisation" theory by means of conceptual arguments from the contents of the Deuteronomic Code, is equally questionable. In a recent review of Weinfeld's opinion, Lohfink cogently maintains that the Deuteronomic code is not in the least concerned with a circumscription of the cultic sphere in favour of a more abstract expression of religion. Quite the contrary, the code develops a new notion of sacrality in which the whole community of Israel, which is especially constituted through festal participation at the central sanctuary, establishes a new sacrum. Lohfink supports his thesis by delineating 
common elements of a "pilgrimage pattern" in various texts of the Deuteronomic Code ${ }^{33}$.

In summary, the preceding critique of "divine law" hypotheses whatever their differences - can be recapitulated as follows. It is not disputed that biblical law codes acquired the distinctive characteristic that they laid claim to divine legitimation. By this means they seem to have appealed to a different authoritative basis than other ancient Near Eastern codes $^{34}$. What is at issue is the recognition of the complex redactional and historical processes which led to the invocation of divine authority. Specifically with reference to the Covenant Code, the naive assumption of divine legitimation - whether it is based on a special form of law, and/or on the primary influence of a body of material such as the Decalogue - places the analysis of biblical law on an erroneous basis. The impression is created that Yahweh's (covenant) sovereignty served as an impetus for the integration of the diverse material which is contained in the code. It is easy to understand that such a view can accord a primary status to the collection of largely apodictic material which is found from Exodus 22:17f ${ }^{35}$. Such a view overestimates the integrative power of the Yahweh faith in at least pre-monarchic Israel, and impedes the search for the social contexts in which early Israelite law developed. What is more, Weinfeld's theory illustrates how a "divine law" approach can lead to fundamental methodological difficulties in the analysis of the development of biblical law.

The "divine law" approach has, however, received far more substantial methodological support in Halbe's detailed redactional analysis of the formation of the Covenant Code. An appraisal of his view forms an indispensable basis for a review of various recent studies which suggest that the redactional growth of the Covenant Code points to a more gradual connection between law and theology.

\section{THE PRIMACY OF THE DIVINE PRIVILEGRECHT IN HALBE'S REDACTIONAL ANALYSIS}

Halbe draws on Weber's use of the term Privileg to refer to a premodern stage of legal development, in which special rights and duties are exclusively enforced within the framework of membership in a particular group. Any person would thus have been involved in a network of personal unions, which constituted "legal communities" within which specific rights and duties were upheld ${ }^{36}$. Halbe transposes the notion of Privileg to the description of the exclusive covenant between Yahweh and Israel. He contends that the redactional development of the Covenant Code, should be 
understood in terms of the progressive incorporation of social and civil stipulations within a body of primary cultic material, or Privilegrecht, which defined the parameters of the basic relationship between Yahweh and Israel.

In support of his thesis, Halbe takes his cue from an old corpus of Privilegrecht which he finds in the text of Exodus 34:10-26*. The original body of material (Ex 34:10a $\beta \mathrm{b}-15 \mathrm{a}, 18 \mathrm{a} \beta^{*} \gamma \mathrm{b}, 19^{*}, 20-21,25^{*}$ and $26 \mathrm{~b}$ ) together with a first amplification in a "Pilgrimage" layer (Ex 34:18a $\alpha$, $\left.a \beta^{*}, 22-23,24 b, 26 a\right)$, can probably be traced back to a distinctive depiction of the Sinai festival at Gilgal in the time of the Judges. Cast in the form of a divine address, the Privilegrecht consisted of an introductory reference to Yahweh's manifestation of his majesty $(10 \mathrm{a} \beta-11 \mathrm{a})^{37}$, which served as the basis for the main commandment in verses $12-15 \mathrm{a}^{38}$, and various individual stipulations in 18-26*39. With its polemic against the indigenous cults and the call to recognise Yahweh by means of festival times and cultic practices, the purpose of the Privilegrecht was to provide a basis for the consolidation of the loose association of tribal groups into a larger communal entity, which could successfully address the challenges of the Canaanite cultural context ${ }^{40}$.

The existence of this older body of Privilegrecht provided the basis for the composition of the Covenant Code from an original layer of material, and two subsequent redactional expansions. The original layer of the code (the "A-Schicht" - Ex 23:23-24,31b-33*; 20:24a $\alpha, 26 \mathrm{a} ; 22: 27-29$; 23:10-12a, 14-19), consists of the introductory warning against the worship of the Canaanite gods, and various sections of purely sacral law41. A subsequent first expansion, ("Ausbaustufe 1" or the "Grundzusammenhang" - Ex 20:24-26, 22:20a $\alpha, 22 b, 24-30,23: 1-7,10-12 a, 13-19)$ integrated two units of material with a social nature - dealing with the protection of marginal groups (Ex 22:20:20a $\alpha, 22 b, 24-26$ ) and the safeguarding of the judicial system (Ex 23:1-7) - with the sacral laws. The main body of the Grundzusammenhang thus consists of two parallel sequences of social $(22: 20 \mathrm{a} \alpha, 22 \mathrm{~b}, 24-26 / 23: 1-7)$ and religious stipulations (22:27-29/23:1012a), which each end with a stylistically similar closing verse (22:30/23:13) $)^{42}$. The conscious redactional modelling of Ausbaustufe 1 as Privilegrecht is evident from two characteristics. Firstly, both units of

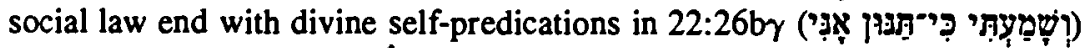

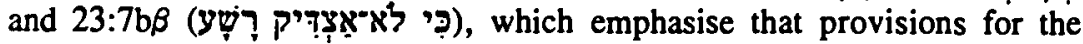
safeguarding of the community fabric present the direct and personal will of Yahweh ${ }^{43}$. Secondly, both verses 20:30 and 23:13, which present the climax of each parallel sequence within this redactional layer, emphasise 
Israel's obligation to honour the exclusive claims of Yahweh ${ }^{44}$. The oral proclamation of the Grundzusammenhang within the cultic realm thus confronted Israel with the concrete demands of the divine Privilegrecht ${ }^{45}$.

In the last redactional phase (Ausbaustufe II), the decisive point was reached at which an old Privilegrecht of Yahweh was transformed into a law book ${ }^{46}$. By means of the incorporation of the whole block of Exodus 21:1-22:19, consisting of a selection of case law precedents which derived mainly from the period of Samuel, the extended Privilegrecht was amplified to include a collection of so-called "Private law" 47. This substantial modification was necessitated by the fact that while pre-monarchic Israel was already forming itself as a "legal community" under Yahweh, the practical organisation of its life was still characterised by the clashes between the judicial norms of various clan groups. The formation of the Mishpatim is an attempt to develop a common set of legal principles, and to accord them authority by grounding them in the "privilege" relationship between Yahweh and Israel ${ }^{48}$. The resultant, qualitatively new composition of the Covenant Code, represents the response of conservative groups to the crisis of the united monarchy. In their view, the basis of Israel's life is to be found in the bond with Yahweh, rather than in the kingship and its institutions ${ }^{49}$.

By virtue of his rigorous redactional analysis, Halbe advances a far more compelling methodological motivation for the argument that the theological nature of Old Testament law is its characteristic and essential quality. His assessment of the relationship between Exodus 34:10-26* and the original layer of the Covenant Code is admittedly somewhat equivocal. Nevertheless, even though he argues against direct literary dependence, he accepts that the "Grundschicht" of the Covenant Code was shaped in the sphere of influence of the Privilegrecht material ${ }^{50}$. Thereby he identifies the conception of the religious relationship between Yahweh and Israel which is found in Exodus 34, as the distinctive basis for the development of the legal and ethical stipulations which are contained in the Covenant Code. The plausibility of Halbe's thesis is of course dependent on the literary-critical status which is allocated to the material in Exodus 34:1026* - a matter which will be dealt with in the discussion of the views of Osumi and Crüsemann.

Quite apart from the question of Exodus 34:10-26*, Halbe's study again raises the problem of legal sanction. Thus he argues that while the corpus of Mishpatim in Exodus 21:1-22:19 had antecedents in existing case laws, it never existed in a form which was separate from the frame of the Privilegrecht ${ }^{51}$. Consequently, the Mishpatim were only able to present a 
common set of judicial norms for the collective life of Israel, by virtue of their incorporation within the divine Privilegrecht. In similar vein, he concedes that the natural authority of community groups stood behind the basic material that is now contained in the social laws (Ex 22:20a $\alpha, 22 b, 24-$ 26/23:1-7)52. Yet is was only through their incorporation within the redactional framework of the Privilegrecht, that such laws began to enjoy collective legitimacy within "Israel". The significance of Halbe's categorical correlation between broader societal recognition and theological authorisation, is that it clearly articulates assumptions which seem to be more implicit in the "divine law" hypotheses which were reviewed in the preceding section. The validatory role which theological considerations exercise in the development of the Covenant Code, is assessed quite differently in the recent studies of Osumi, Crüsemann, SchwienhorstSchönberger and Otto.

\section{THE THEOLOGISATION OF LAW IN RECENT ANALYSES OF THE COVENANT CODE}

\subsection{Osumi and Crüsemann}

The methodological assumptions which characterise the works of Crüsemann and the revised doctoral dissertation of his student Osumi, are sufficiently similar to warrant concurrent assessment. The following remarks will focus on the more extensive analysis of Osumi. His redactional construction, which is closely followed by Crüsemann, defines itself as a conscious engagement with the views of Halbes3. Osumi understands the formation of the Covenant Code as a two stage process which consisted of successive second person singular and plural redactions. The basic structure of the code was shaped by a second person singular redactional layer, which was authored between the late eighth and early seventh century BCE as a product of the so-called Jerusalem high court. This redaction, which stretches from Exodus 20:24-23:33, consists of a Mishpatim (21:2-22:19) and "Wisdom" (22:20-23:33) section ${ }^{54}$. The Covenant code assumes a quite different texture at the hands of a subsequent second person plural redaction, which was responsible for the final shape of a main unit which extends from Exodus 21:1 to 23:1355.

The discussion will focus on the factors which facilitated the integration of law within the divine will in the formative second person singular redaction. It may merely be noted that Osumi finds quite distinct theological impulses, which he traces to the influence of the Jerusalem 
holiness tradition, at work in the final, proto-Deuteronomistic redaction ${ }^{56}$. His analysis of this last compositional phase, raises the important question of the influence of the Jerusalem holiness tradition on the shaping of the Covenant Code. While this matter will not be pursued here, it will receive further attention in the review of Otto's work.

A number of themes which are dealt with in both the "Wisdom" and Mishpatim sections of the code, point to the catalyst which brought about its basic configuration at the hands of the second person singular redaction. Thus, both Crüsemann and Osumi relate the problem of the "resident alien" (רג), which is mentioned in Exodus 22:20,22 and 23:9, to the refugees who fled to Judah, and especially Jerusalem, after the fall of the northern kingdom ${ }^{57}$. Within the "Wisdom" section, the importance of the "alien" theme is clear from the pivotal role which Exodus 22:20a and 23:9a* play as frame verses around the body of social laws in the unit of Exodus 22:20a-23:9a*58. Osumi also makes a detailed comparison between the sections which deal with pledges (Ex 22:24a,25-26) and judicial procedure (Ex 23:1-8), and Amos 2:6-8 and 5:10-1259. His attempt to demonstrate the code's literary dependence upon the Amos units may be contentious. Nevertheless, the correspondences between the material create a plausible social context, within which at least the protection laws of Exodus 22:20-26* could have arisen. The promulgation of such measures during the late eighth century $\mathrm{BCE}$, reflects growing concern at the injustices which were occasioned by the system of rent capitalism, and the process of latifundialization against which the eighth century prophets inveighed so forcefully60.

According to Osumi, such concern also led to the insertion of the slavery laws of Exodus 21:2-11 and 24-27 within the Mishpatim material by the second person singular redaction ${ }^{61}$. Crüsemann's assessment of the slavery sections marks his most significant difference from Osumi. Both Exodus 21:2-11 and 26-27 form part of the original body of Mishpatim, and reflect its concern for a balance between the rights of two parties ${ }^{62}$ - in this case that of slaves and slave owners. However, the effect of the promulgation of the Mishpatim within the increasingly disparate monarchic society of the ninth century BCE, was to entrench the exploitative capabilities of slave owners. The secondary insertion of the talion laws (Ex 21:2425) within the second person singular redaction, served as a substantial critique against such exploitative practices ${ }^{63}$. This difference of opinion in no way invalidates Crüsemann and Osumi's basic contention that the literary creation of the Covenant Code is a corollary of societal developments in late eighth century BCE Judah. 
As has already been mentioned, Osumi's delineation of the constitutive second person singular redaction involves itself in an extensive debate with Halbe's analysis. In terms of the specific interests of the present discussion, it is particularly significant to note how Osumi departs from Halbe's thesis in his assessment of the Mishpatim section (21:2-22:19). In his view, this part of the code contains a basic layer of material (Ex $21: 1,12,15-17,18-23,28-36 ; 21: 37-22: 16 ; 22: 17-19)$, which had an independent existence before its incorporation into the Covenant Code ${ }^{64}$. In their attempts to reconstruct the contents of this earlier body of legal material, Osumi and Crüsemann appeal to the judicial authority which 2 Chronicles 19:8-11 purportedly attributes to the Jerusalem court ${ }^{65}$. According to Osumi, the areas of competence of this alleged court reveal an original corpus within the Mishpatim which consisted of two units, dealing with capital delicts and bodily injuries (Ex 21:12-36*)66, and property delicts (21:37-22:16). Given the problems that adhere to the historicity of the Chronicles text ${ }^{67}$, its use in the determination of the primary stratum of the Mishpatim section is extremely questionable. Despite such methodological difficulties, Crüsemann and Osumi's analyses constitute a significant break with the assumptions of the "divine law" hypothesis. Their demarcation of a body of precepts which owed its broader, societal validity to the exigencies of ordinary judicial life, asserts that the authorisation of such civil laws within ancient Israel was in no sense dependent on an association with an originary body of divine law.

However, once Crüsemann and Osumi turn to the processes which occasioned the theological motivation of law within the second person singular redaction, the influence of the older "divine law" hypothesis, and specifically Halbe's thesis concerning the body of divine Privilegrecht in Exodus 34:11-26*, is immediately apparent. The basic configuration of the Covenant code presents the reworking and elaboration of the older section of casuistic law in the Mishpatim section, as well as the creation of the "Wisdom" section (20:24-26; 22:20a,22,24a,25-29; 23:1-8,9a,10$\left.12,13 b^{*}, 14-21 a, b \beta, 22-23 a, 24,32,33 b \beta\right)$ through the reformulation of the cultic stipulations of Exodus 34:11-2668. The preceding discussion has already indicated how problems such as the presence of resident aliens and the impact of rent capitalism, would have necessitated the amplification of the basic cultic prescriptions which were incorporated within the "Wisdom" section by social measures. Thereby the conviction was expressed that without protection of the weak and without social justice, Israel would loose its identity as the people of God ${ }^{69}$. Despite differences in date, the literary processes which Osumi and Crüsemann trace in the 
compilation of the "Wisdom" section - i.e dependence on Exodus 34, and amplification of cultic regulations by social stipulations - show remarkable analogies to Halbe's analysis. Halbe's influence is further evident in Osumi's assertion that the "Wisdom" section formed the basis for the redactional incorporation and expansion of the Mishpatim section within the newly created $\operatorname{code}^{70}$. At the level of the second person singular redaction, therefore, "law" - consisting of ius, fas and ethos - receives an explicit theological motivation through a redactional process which adapted and augmented the old divine Privilegrecht so that it could include the realms of ethical and legal practice.

Osumi and Crüsemann's recourse to the divine Privilegrecht as embodied in Exodus 34:11-26, as the major clarificatory principle for understanding the process of the theological legitimation of law in the Covenant Code, is contentious. Despite their departure from a "divine law" hypothesis, they still assume that cultic and sacral laws provided the basis for the integration of civil law and ethical stipulations under the will of Yahweh. It may be asked to what extent their studies have broken with discredited methodological assumptions concerning the primary validation and subsequent development of Israelite law, by means of its association with the cultic sphere.

Furthermore, their theories hinge on the redactional status which is assigned to Exodus 34:11-26. Reference has already been made to Halbe's intricate literary-critical defence of an old corpus of Privilegrecht within this text. Crïsemann argues for the recognition of an original body of cultic principles in Exodus 34:11-26 (34:12abß,14,15abß,16,18a*,21$23,24 b, 26 a)$, which reflect the social and religious challenges which the Yahweh faith encountered during the ninih century BCE (particularly from the Omride period onwards) ${ }^{71}$. Such a thesis contrasts sharply with the views of scholars such as Aurelius, Blum and Schreiner who view the material in Exodus 34:11-26, as Deuteronomistic (Dtr), and Nicholson who basically accepts Perlitt's view on the Deuteronomic (Dtn) classification of the material in Exodus 34:10-2772. In my opinion, it is possible to maintain with Crüsemann that Exodus 34:11-26 contains older, pre-Dtn/Dtr material. One may refer to Zenger's extensive redactional analysis of the Sinai material in Exodus 19-34, in which he allocates the short "legal corpus" in Exodus $34: 10-27^{*}$ to the Jehowistic configuration of the preceding tradition during the late eighth century $\mathrm{BCE}^{73}$. More recently Dohmen has argued that it is possible to go behind the Dtr redaction of Exodus 34 to establish the presence of a Jehowistic layer of Privilege law in Exodus 34:6-7,12-14*,18-26*, which served as an impetus for the 
formation of the primary version of the Decalogue in Deuteronomy $5^{74}$. Zenger, Crüsemann and Dohmen all establish different textual profiles of the pre-Dtr material in Exodus 34:11-26. Yet their studies at least support the identification of a pre-Dtr body of Privilege law within this textual unit.

It is quite another issue, however, for Halbe, Crüsemann and Osumi to contend that the second half of the Covenant Code (Ex 22:20ff - the "Wisdom" section) was composed in conscious literary dependence on Exodus 34. Such an opinion raises complex literary and ideological questions, which it is impossible to review within the confines of the present paper. A few remarks must suffice. Firstly, the festival order which is found in Exodus 34:18-23* clearly predates that of Exodus 23:1419 , especially in terms of the original relation of the rest-day to the time between the Mazzot festival and the festival of Weeks ${ }^{75}$. However, the presence of analogies between the two sections does not necessarily demonstrate literary influence on the Covenant Code in the decisive stage of its pre-Dtr redactional formation. Rather, the passage of Exodus 23:1419 may be classified as a Dtr insertion, for the purpose of emphasising the correspondence between the legal material in the Covenant Code and Exodus 3476. As far as the relationship between Exodus 23:20-33 and Exodus 34:11-16 is concerned, reference can be made to Blum's discussion of these texts in conjunction with the related units of Judges 2:1-5 and Deuteronomy 7. Following Blum this paper accepts that Exodus 23:20-33 presents part of the Dtr epilogue to the Covenant Code, in which the theme of the separation of Israel from the foreign nations is used to stress the importance of the main commandment ${ }^{77}$.

The allocation of both the units of Exodus 23:14-19, and 23:20-33 to the level of Dtr redaction, decisively undercuts the thesis of Halbe, Crüsemann and Osumi. The material in these units plays a critical role in their delineation of the constitutive redactional formation of the Covenant Code. If such material is viewed as Dtr, then a quite different picture of the pre-Dtr compositional formation of the Covenant Code is necessitated. Put differently, the formation of the so-called "Wisdom" section cannot have taken place in the way which Crüsemann and Osumi suggest. Logically, the entire redactional process which shaped the code has to be understood differently.

In sum, the argument that the theological motivation of law presents a secondary development which took place in the late monarchic period as a response to social problems, is a valid and important insight. However, the thesis that this process took place on the basis of a body of divine Privilegrecht in Exodus 34:11-26* is untenable. A different reconstruction of the integration of law and theology in the Covenant Code is required. 


\subsection{Schwienhorst-Schönberger}

Schwienhorst-Schönberger's analysis shares various common assumptions with the works of Osumi and Crüsemann. He also opts for a literary model, in terms of which the Covenant Code was formed through the reworking of a basic series of casuistic stipulations by two successive redactions. The basic structure of the Covenant Code (Ex 20:24-23:19) derives from a massive pronto-Deuteronomistic Gottesrecht redaction from the late eighth century BCE, which is characterised by a second person singular form of address. This redaction extensively reworked the material of a casuistic law book, found in Exodus 21:12-22:16*, whilst also incorporating the bulk of the material which is contained in the second half of the Covenant Code, namely Exodus 22:17-23:1978. The process of the theological integration of law was continued in a subsequent Deuteronomistic (DtrN) redaction, which is mainly characterised by a second person plural form of address ${ }^{79}$. Without changing the structural arrangement of the Covenant Code, this revision merged the existing material into the comprehensive framework of the Deuteronomistic History (DtrN). The present discussion will focus on the Gotresrecht redaction, and the compositional processes which led to its formation.

Schwienhorst-Schönberger concurs with Osumi and Crüsemann that the theological legitimation of law within the Covenant Code presents a secondary stage of its redactional development. However, he furnishes a more convincing explanation of the societal and judicial processes which accompanied the formation of the basic casuistic law book. The major part of his work indicates how the casuistic law book developed as a body of profane law before its inclusion in the Gottesrecht redaction ${ }^{80}$. He convincingly relates the primary layer of Exodus 21:12-22:16 to an egalitarily structured agricultural and pastoral culture based on kinship ties and living in open towns or settlements - a situation which can be understood against the background of the newly founded town culture in Palestine during the Iron Age 1 period (1200-1000 BCE) ${ }^{81}$. The book owes its origin and first editorial expansions to the interplay between legal praxis - the shaping of common law through the judicial activity of the clan elders at the gate, and Israelite scribal schools - the locale where the common law was collected, modified and codified82. Until the eighth century, the developing collection of casuistic law served as a basis for conflict resolution, enjoying a normative character that was not appreciably greater than that of common law. It is was through the decisive Gottesrecht 
redaction, that the casuistic law received a new validatory basis in the will of Yahweh ${ }^{83}$. The evolution of the Covenant Code is thus understood in terms of the development from profane to divine law.

The continued activity of the scribal schools led to the literary formation of the Covenant Code, as a response to societal developments in the eighth century BCE. For a clear example of the modification of the old casuistic law book by the Gottesrecht redaction, Schwienhorst-Schönberger points to the laws of asylum in Exodus 21:13-1484. These laws present a secondary qualification of the participially formulated prohibition of homicide in Exodus 21:12, which immediately preceded the provisions concerning non-fatal bodily injuries from Exodus $21: 18 \mathrm{ff}$ as the introduction to the earlier law book ${ }^{85}$. Both the stylisation of the asylum laws as a divine address which is directed to a second person singular audience, as well as the concern of these laws to limit the operation of blood vengeance, serve as important indications of the literary and ideological characteristics of the Gottesrecht redaction. Through verses 13-14, the whole section of Exodus 21:12-17 - in which verses 15-17 are also regarded as the product of the Gottesrecht redaction ${ }^{86}$ - assume the quality of a divine address which now provide an introduction to the first main part of the Covenant Code in Exodus 21:18-22:1687. Within the contours of Exodus 21:18$22: 16$, further indications of the redaction's concerns are found in insertions which deal with debt-slavery (Ex 21:20-21,26-27) and additional provisions for the limitation of blood vengeance (Ex 21:23-24 [the talion law]; Ex 21:30 and 22:1-2) ${ }^{88}$. Finally the reference to the use of an oath to Yahweh in Exodus 22:10, reflects a development in procedural law with respect to the resolution of unsolved property disputes ${ }^{89}$.

The interests of the Gottesrecht redaction are far clearer in the second main part of the code (Ex 22:17-23:9), as well as in the corresponding units of Exodus 21:1-11 and 23:10-1290, and 20:24-26 and 23:14$19^{91}$, which provide the code with two outer frames. The redaction created part of this material de novo, and shaped the rest on the basis of a variety of extant material. At this compositional level, Exodus 22:17-23:9 displays a concentric structure in which social laws (22:20-26*/23:1-7) encompass a unit of religious provisions ${ }^{92}$. The divine self-predications in Exodus $22: 26 \mathrm{~b} \gamma$ and $23: 7 \mathrm{~b} \beta$, reinforce the humanitarian concern which links the sections concerning the protection of marginal groups (22:20-26*) ${ }^{93}$ and the safeguarding of judicial procedure (23:1-7)94. Such charitable concern is of course also apparent in the corresponding frame sections which deal with debt slavery (21:1-11), and the fallow year and rest day (23:10-12).

As has already been stated, the programme of the Gottesrecht redaction correlates with the societal situation in the eighth century BCE. 
Similarly to Osumi, the debt slavery laws are understood against the background of the prophetic activity of Amos ${ }^{95}$. The prophetic critique of Hosea against the monarchy, is manifested in the reference to the ruler as a צִ iִ Exodus 22:2796, while traces of Hosea's censure of non-Yahwistic cultic practices may also be displayed in the form of the altar law in the Gottesrecht redaction (Ex 20:24a $\left.\alpha \beta^{*} \mathrm{~b}, 25-26\right)^{97}$. The upshot of Schwienhorst-Schönberger's analysis is a redaction with a strong humanitarian concern (especially Ex 21:2-11, 15-17, 20-21, 26-27; Ex 22:20a $\alpha, 21 \mathrm{~b}$, $24 a^{*}, 25-26 ; 23: 10-12$ ), intent on the equitable dispensation of justice (22:10, 23:1-8) which would include the balancing of the rights of both parties in legal disputes (Ex 21:20-21; 22:1-2) as well as the limitation of the principle of blood vengeance (Ex 21:13-14, 23-24, 30; 22:1-2). Emphasis was placed on respect for societal authority structures in both religious and political dimensions, and on the recognition of Yahweh in cultic practice.

A useful aspect of Schwienhorst-Schönberger's analysis, is his recognition that the Gottesrecht redaction had to accommodate itself to the contours of the older casuistic law book in its literary activity. The resultant dominance of ius in the first part, and fas and ethos in the second part of the code, presents a proto-Deuteronomic stage, which is still en route to the thorough interrelation of ius, fas and ethos in the Deuteronomic laws ${ }^{98}$. The influence of the older law book is apparent from a further interesting detail, to which Schwienhorst-Schönberger draws attention in his delineation of the code's structure ${ }^{99}$. The preceding discussion has already pointed to the concentric structure which characterises the second main part of the code (Ex 22:20-23:7(9)). In the first main part (Ex 21:18-22:16), however, the extant textual material precluded the creation of a similar concentric structure. As a result, the redaction was forced to follow other structuring principles. This structural detail reinforces Schwienhorst-Schönberger's argument concerning the priority of the casuistic law book in the development of the Covenant Code.

Schwienhorst-Schönberger's study presents a compelling reconstruction of the processes which, in his view, occasioned the creation of the basic form of the Covenant Code as a book of divine law. His basic thesis concerning the development from profane to divine law is convincing, while he also substantially clarifies the societal developments and concerns which informed the production of the code as an expression of Yahweh's will. In addition, the fact that he does not appeal to Exodus 34 as the cardinal literary impulse for the formation of the Gottesrecht redaction, must certainly be welcomed. The important methodological question of 
whether a consistently literary approach represents an adequate basis for assessing the redactional growth of the code, cannot be addressed in the present discussion. More pertinent to the problem under consideration, is that Schwienhorst-Schönberger hardly addresses the question of the theological concepts which motivated the Gottesrecht redaction. There is a difference between describing the concerns of the redaction, which he does extensively, and explaining the decisive theological considerations by which they were motivated. In other words, if the clarificatory principle of an older divine Privilegrecht is refuted, which theological tendencies are at work in the contention that Yahweh is finally the author of Israelite law? For all its positive aspects, it is intriguing that Schwienhorst-Schönberger's analysis never addresses this issue. Does he imply that it is not possible to understand the basis upon which law was subjected to a process of theological legitimation, or did he deliberately leave the matter open pending further investigation?

\subsection{Otto}

In accord with the works of Osumi, Crüsemann and Schwienhorst-Schönberger, Otto accepts that the pre-Deuteronomistic redactional phase which gave the Covenant Code its decisive shape, and which was responsible for the theological authorisation of the material, took place in the late monarchic period ${ }^{100}$. He also identifies a subsequent Deuteronomistic redaction, mainly distinguished by the use of the second person plural form, which embedded the code within the Sinai pericope. Except for his allocation of Exodus 23:14-19 to this layer, his assessment of the final compositional phase is very similar to that of Schwienhorst-Schönberger ${ }^{101}$. The following remarks will primarily deal with the theological impulses which motivated the pre-Deuteronomistic redactions.

Otto adopts a sharply different methodology than Osumi, Crüsemann and Schwienhorst-Schönberger in tracing the development of the legal material before the phase of its decisive systematisation into the basic form of the Covenant Code. Firstly, he maintains the validity of form-critical categories in distinguishing the evolution of smaller collections of law, and reconstructing the development of Israelite legal history which is reflected by these units. The code was thus constructed on the basis of a series of smaller legal collections, whose development reflects a sophisticated transmission-historical process of systematisation and rationalisation ${ }^{102}$. Secondly, he relates the growth and redaction of the units to a specific legal sociological model which he applies to the societal evolution of 
ancient Israel. In terms of this model, the ability to impose sanctions was originally limited to the innergental sphere (cf. Ex 21:12,15-17), except for urgent cases of intergental conflict, whilst the judicial authority which was exercised in the local community had a purely conflict regulating status. The qualification of the apodictic series of Exodus $21: 12,15-17$ by the casuistic sentences of Exodus 21:13-14, points to the transfer of a sanction function to the local judicial authorities - a development which is further exemplified in introduction of a penalty function within the various units of casuistic law between Exodus 21:18-22:16. The change from a premonarchic segmentary tribal community to a vertically structured state, was a major catalyst in the differentiation of penal laws from laws with a purely compensatory function. The increasing sophistication and differentiation of law is also illustrated by developments in procedural law (cf. Ex 23:1-8) ${ }^{103}$, as well as in provisions for the protection of debt slaves (Ex 20:20-21,26-27)104. Otto's reconstruction of the development of Israelite law raises crucial methodological questions, which are in need of extensive further reflection.

In terms of the problem of law and theology, Otto makes the significant contention that the increasing economic and social polarities of monarchic society led to a situation in which law gave way to ethos ${ }^{105}$. He traces this process in the sections which deal with debt slavery (Ex 21:1$11)^{106}$, procedural law (verses 4-5 within Ex 23:1-8) ${ }^{107}$, and especially in the social protection laws which deal with the exploitation of the resident alien and the lending of money against a pledge in Exodus 22:20-26*108. While the nature of the ethical injunction remains mainly implicit in Exodus 21:2-11, it is explicit in the appeal for insight into the plight of the poor on the basis of social solidarity (Ex 22:24a $\left.\alpha^{*}, 26 \mathrm{ab} \alpha\right)^{109}$ within the unit of Exodus 22:20-26*110. However, the continuing deterioration of the social fabric necessitated the appeal to a theological basis for the validity of law. This decisive phase was characterised by the integration of the smaller collections of laws into two chiastically arranged major redactions - in Exodus 21:2-22:26* and Exodus 22:28-23:12 respectively - which each appealed to different concepts as a theological basis for the laws of the Covenant Code"11.

The interests of the first major redaction are particularly reflected in the units of Exodus $21: 2-11$ and $22: 20-26^{*}$ which stand in chiastic relationship around the material in Exodus 21:12-22:19. Otto points to the implicit theological motivation within the unit of Exodus 21:2-11. The use of the $6 / 7$ scheme, which has its origins within the cultic sphere, signifies the reservation of certain times and matters for Yahweh's disposition"12. 
Otto seems to argue, though, that the first redaction has suppressed this theological concept in favour of the notion of divine kingship which is expressed in Exodus 22:20-26*. Within this unit, it is especially the selfdepiction of Yahweh by means of the term 190 in Exodus 22:26by, but also the relationship of the injunctions concerning pledges to the temple entrance liturgies in Psalm 15 and 24, which point to the notion of the merciful divine king who takes up the cause of the powerless. The first redaction's predilection for this concern, which is strongly rooted in the Jerusalem cult theology, indicates that it should be understood as the product of the Jerusalem priesthood in the late monarchic period ${ }^{113}$.

In his 1988 monograph, and various subsequent publications, Otto has related the second redaction to Judaic rural Levites, who found a new basis for the ethical motivation of law in a theology of land. Taking their cue from basic stipulations concerning the fallow year and rest day, the frame sections of Exodus 22:28-29 and 23:10-12 express the reservation of various aspects of Israel's life for the exclusive privilege of Yahweh ${ }^{114}$. The distinctive aspect of this redaction lies in its use of a theology of divine privilege to integrate ius, fas and ethos within Yahweh's will. The terminus $a$ quo for this late pre-exilic redaction is the eighth century BCE. Against Halbe, Otto thus contends that a theology of divine privilege is a late phenomenon within the development of ancient Israelite law ${ }^{115}$.

The pre-Deuteronomistic redaction formed the Covenant code through the fusion of the two collections, thereby creating a legal corpus which was framed by the debt-slavery (Ex 21:2-11) and fallow and rest day stipulations (Ex 23:10-12). Building on the theological impulses of the second independent redaction, the common $6 / 7$ scheme within these units symbolises the way in which the theology of divine privilege becomes the dominant perspective which undergird the authority of the sacral, legal and ethical provisions within the Covenant Code ${ }^{16}$. Within Otto's analysis, therefore, the link between Exodus 21:2-11 and 23:10-12 presents a secondary development, which abrogated the primary connections of the two units (Ex 21:2-11/22:20-26*; and Ex 22:28-29/23:10-12) in the Jerusalem and levitical redactions.

In an as yet unpublished paper ${ }^{117}$, Otto has significantly modified his theory, by arguing that the depiction of Yahweh as the divine king in the first major redaction reflects the influence of solar imagery on a priestly theology of the Jerusalem temple. Accordingly, he no longer attributes the second major redaction to rural Levites, but rather to priestly circles in Jerusalem, who reacted against the increasing solarisation of the Yahweh religion in the Neo-Assyrian period, by legitimating the laws of the Covenant Code in terms of a theology of divine privilege. 
Otto's description of the processes which led to the integration of law and theology within the Covenant Code is extremely complex. The present discussion will have to content itself with a few cursory comments about his provocative argument concerning the shift from a theology of divine kingship to a theology of divine privilege as the basis for the code's authority. Firstly, it must be demonstrated that Exodus 22:26b $\gamma$, which is the only Old Testament text in which pon on its own serves as a predicate of Yahweh, can be related to the notion of divine kingship. The analysis of various Psalm texts (Ps 86:15, 103:8, 111:4, 145:8), in which the term jạn occurs together with or less explicit reference is made to God's kingship, must play a crucial role in this regard ${ }^{118}$. The dating of Psalm material is of course notoriously difficult. Even if these psalm texts are assigned a post-exilic date ${ }^{119}$, it could be argued that the credal formula itself is an old cultic expression which has its roots in epithets of the divine king El120. A more extensive analysis could, therefore, adduce plausible grounds for an association between the use of the term Yahweh's merciful kingship.

Secondly, Otto has already investigated conceptual parallels between Exodus 22:20-26* and the so-called "entrance liturgies" in Psalms 15 and 24 , in a study of cult and ethos in the Jerusalem theology121. It is interesting to note that Psalm 15 grounds social and cultic norms, including the prohibition of interest (Ps 15:5a), within the cultic affirmation of the kingship of Yahweh who dwells in Zion. To my mind, both Psalms 15 and 24 can be understood in relation to an announcement of ethical requirements before participation in the temple cult, a practice for which there are at least analogies in the Ancient Near East ${ }^{122}$. Further analysis of Psalms 15 and 24 in the light of the pre-exilic Kingship psalms - Psalm 93 and 47123 - could help to clarify the notion of divine kingship which was at home in the Jerusalem temple, and which may have provided a context for the theological legitimation of law within the Covenant Code.

Thirdly, there is the matter of the solarisation of Yahweh in the Jerusalem temple theology. The recent work of Janowski has amply demonstrated the responsibility of the solar deities of the Ancient Near East for the maintenance of justice ${ }^{124}$. Recently, Keel has also argued for a pre-Israelite solar cult in Jerusalem ${ }^{125}$. Amongst the textual evidence which has been amassed by Stähli126, Otto cites 2 Samuel 12:11-12; 2 Samuel 23:3b-4 and Psalm 72:1-2,5,17 to indicate the connection of solar motifs with the Judaean kingship ideology. Evidence of the influence of solar imagery in the Neo-Assyrian period, can be found in imprints of the 
winged sun and four winged scarabs on royal ( $\mathrm{mmlk}$ ) seals from the late eighth and seventh century in Judah'27, and discoveries of horse figurines with a sun disk above their heads at Iron Age levels (9th-7th century BCE) trom Hazor, Lachish and Jerusalem ${ }^{128}$. Current scholarship is still investigating the question of the possible influence of solar motifs on the understanding of Yahweh, and it is still far from clear that solar motifs stand behind the theological validation of law in the Covenant Code.

Fourthly, and finally, Otto's assertion that two independent collections of material (Ex 21:2-22:26/ 22:18-23:12) preceded the redactional composition of the Covenant Code at the pre-Deuteronomistic level remains problematic. It is difficult to accept that the clear parallels between Exodus 21:2-11 and 23:10-12 could only have been the result of a secondary link between these units. As Schwienhorst-Schönberger argues, the considerations which Otto advances to establish a stylistic link between Exodus 21:2-11 and 22:20-26* are not convincing ${ }^{129}$. What is more, Otto does not adequately clarify why the first independent redaction should suppress the theology of divine privilege which it found in the $6 / 7$ scheme of Exodus 21:2-11, in favour of the notion of a theology of divine kingship. It is thus questionable whether there are sufficient grounds to accept the existence of two originally independent redactional blocks as the basis for the definitive composition of the Covenant Code.

In sum, Otto's analysis has opened up fresh paths for exploring the theological intentions which guided the attribution of law to Yahweh's will in the Covenant Code. The accentuation of the notion of divine kingship as a significant motivation for the code's authority is suggestive. Furthermore, his assessment of the relatively late influence of a theology of divine privilege, represents an important corrective to the view of Halbe. In my opinion, the manner in which he reconstructs the influence of the Privilegrecht, is also more convincing than the theses of Crüsemann and Osumi with their dependence on Exodus 34. One of the important questions which still needs clarification, however, is how the notions of divine kingship and divine privilege could correlate to lend authority to the code. Given the problems that adhere to Otto's redactional model, the processes and considerations which led to the integration of law and theology within the code still require substantial clarification.

\section{CONCLUDING OBSERVATIONS}

As the earliest extant legal collection, the Covenant Code provides a crucial key for understanding the development of law within ancient Israel. 
Contrary to the contentions of "divine law" hypotheses, the paper has argued that the divine will - and its cultic affirmation - did not provide the primary catalyst for the evolution of the judicial process. Rather, as the results of recent redactional analyses of the Covenant Code have demonstrated, the integration of law and theology occurred at a more advanced stage. Consequently, the primary development of ancient Israelite law reflects the exigencies of changing societal contexts from the time of the pre-monarchic period. During such earlier phases, the authority of legal stipulations was entirely dependent on the social institutions by which they were promulgated. A pivotal question is how far the material in the Covenant Code can be used to reconstruct judicial processes during this basic period. It is clear that Otto, by virtue of the use of form-critical categories, derives a far more elaborate picture of legal development from the code than either Schwienhorst-Schönberger or Osumi. In further study of Israelite law, the merits of Otto's form-critical approach need to be weighed up carefully against the consistently literary models which are advocated by Schwienhorst-Schönberger and Osumi.

Furthermore, greater clarification is needed concerning the processes and theological concepts which accompanied the attribution of law to the divine will. The recent studies have substantially elucidated the societal problems which necessitated such a shift in the authoritative basis of law. Yet, beyond such consensus, there is much that remains disputed. Against Crüsemann and Osumi, this study has argued that the body of preDeuteronomistic Privilegrecht in Exodus 34:11-26, did not play the constitutive role in the theological redaction which produced the Covenant Code. It has also asserted that Otto's recourse to Jerusalem cultic traditions, and specifically the notion of divine kingship, may present a fruitful avenue for further research into the theological impulses which are at work in the code. The correlation between such a concept and the notion of divine privilege which is clearly present in Exodus $21: 2-11$ and 23:10-12, requires further consideration - especially in the light of the fact that the redactional arrangement of the Covenant Code remains intriguingly unclear.

I would like to end with a brief remark on the relevance of all this reflection on law and theology within the ancient Covenant Code, for the church's contemporary ethical task. The realisation that the theological legitimation of law presents a secondary response to the increasing complexity of Israelite society, opens up interesting perspectives for the task of actualising God's presence in society. The rapidly changing face of the modern world, with all its uncertainties and incongruities, challenges theology to search for concepts and premises which can facilitate the 
realisation of justice. The fusion of ius, fas and ethos, within the Covenant Code militates against the modern tendency to separate the sphere of law from questions of ethos. It also challenges members of the diverse religious traditions who attach some authority to this material, to assume responsibility for matters of justice and the entrenchment of a culture of human values in contemporary society. As the Covenant Code indicates, God is not only served in the sacral realm, but in every aspect of the social fabric.

\section{NOTES:}

1 E Otto, Wandel der Rechtsbegrandungen in der gesellschafisgeschichte des antiken Israel. Eine Rechtsgeschichte des "Bundesbuches" Ex XX 22 -XXIII 13, Leiden 1988, 72.

2 F Crüsemann, Die Tora. Theologie und Sozialgeschichte des altrestamentlichen Geserzes, München 1992, 95; Otto, op cir, L Schwienhorst-Schōnberger, Das Bundesbuch. Studien su seiner Entstehung und Theologie (BZAW 188), Berlin 1990; and Y Osumi, Die Komposition des Bundesbuches Exodus 20,22b-23,33 (OBO 105), Freiburg, 1991.

3 J Halbe, Das Privilegrecht Jahwes Ex 34,10-26. Gestalt und Wesen, Herkunft und Wirken in vordeuteronomischer Zeit (FRLANT 114), Göttingen 1975.

4 Cf $\mathbf{R}$ Westbrook, Studies in biblical and cuneiform law (Cahiers de la Revue Biblique 26), Paris 1988, 1-7; idem, "What is the Covenant Code?" in: Theory and method in biblical and cuneiform law. Revision, interpolation and development (Edited by B M Levinson; JSOTS 181), Sheffield 1994, 15-36.

5 C Carmichael, The origins of Biblical law: The decalogues and the Book of the Covenant, Ithaca 1992, 2-10.

6 J W Marshall, Israel and the book of the Covenant. An anthropological approach to Biblical law (SBLDS 140), Atlanta 1993.

7 A Jepsen, Untersuchungen zum Bundesbuch (BWANT 41), Stuttgart 1927, 96105.

8 A Alt, Essays on Old Testament history and religion, Oxford 1966, 111-123.

$9 \quad$ Alt, op cit, 123-131.

10 Alt, op cit, 103-108, 131-132.

11 M Noth, The history of Israel, London 1960, 100-104; idem, The laws in the Pentateuch and other studies, London 1984, 28-36. 
12 Alt, op cit, 91-92; Noth,op cit, 1960, 102, 108-109. On the activity of the local legal community at the town gate, see the classic discussion of L Kohler, Der hebralsche Mensch. Eine Skizze, Tübingen 1953, 143-175. Köhler is largely followed by Boecker, in his delineation of legal administration in ancient Israel. See $\mathrm{H} \mathrm{J}$ Boecker, Law and the administration of justice in the Old Testament and Ancient East, London 1980, 27-40.

13 Noth, op cit, 1960,100-101; and 1984, 36-41, 49-60.

14 A Weiser, Samuel. Seine geschichtliche Aufgabe und Religiose Bedeutung (FRLANT 81), Göttingen 1962, 9-11. For views on the text as Dtr, see M Noth, The deuteronomistic history (JSOTS 15), Sheffield 1981, 47-49, and the review of scholarly opinions in R de Vaux, The early history of Israel: From the entry into Canaan to the period of the Judges, London 1978, 763.

15 Cf W Eichrodt, Theology of the Old Testament: volume 1, London 1961, 74-82.

16 E Gerstenberger, Wesen und Herkunft des sogennanten apodikrischen Rechts im Alten Testament, Bonn 1961, 29; M Weinfeld, "The origin of the apodictic law", VT 23 (1973), 64-70. Weinfeld finds parallels to the apodictic sections in the Covenant Code in the Hittite "Instructions", and also in Assyrian records of legal ordinances which a king imposed on his subjects. As is well known, various scholars had previously pointed to the Hittite suzerainty treaties as a source of origin for apodictic laws - cf G E Mendenhall, "Ancient Oriental and Biblical law", BA 17 (1954), 26-46; W Beyerlin, “Die Parănese im Bundesbuch und ihre Herkunft" in: Gottes Wort und Gottes Land (Festschrift H-W Hertzberg, Hrsg. H G Reventlow), Göttingen 1965, 9-29.

17 Gerstenberger, op cit, 33-35.

18 Cf $\mathrm{H}$ Donner, Geschichte des Volkes Israel und seiner Nachbam in Grundzügen. Teil 1: Von den Anfangen bis zur Staatenbildungszeit (GAT 4/1), Göttingen 1984, 62-66, 146-148.

19 Cf De Vaux, op cit, 751-773; H Niehr, Rechtsprechung in Israel. Untersuchungen zur Geschichte der Gerichtsorganisation im Alten Testament (SBS 130), Stuttgart 1987, 55-56; Crüsemann, op cit, 82.

20 Niehr, op cit, 1987; Crüsemann, op cit, 81-121.

21 Gerstenberger, op cit, 81-85, 94-95.

22 M Greenberg, "Some postulates of Biblical Criminal Law" in: Yehezekel Kaufman Jubilee Volume (Studies in Bible and Jewish religion dedicated to Yehezekel Kaufman on the occasion of his seventieth birthday, Edited by $\mathbf{M}$ Haran), Jerusalem 1960, 11. 
24 S M Paul, Studies in the book of the Covenant in the light of Cunevform and Biblical law (VTS 18), Leiden 1970, 29-36.

25 In fact, the co-mingling of ius, fas and ethos is regarded as a logical consequence of the ascription of all instnction to the divine will. Cf Greenberg, op cit, 11; Sonsino, op cit, 205; Paul, op cit, 37.

26 Greenberg, op cit, 5-28; Sonsino, op cit, 202-209; Paul, op cit, 37-40.

27 Donner, op cit, 148; Boecker, op cit, 135-144.

28 M Weinfeld, “The Decalogue: Its significance, uniqueness, and place in Israel's tradition" in: Religion and law: Biblical-Judaic and Islamic perspectives, (Edited by E B Firmage, B G Weiss \& J W Welch), Winona Lake 1990, 3-47. The priority of the decalogue of Ex 20 in the formation of the Old Testament legal material is also emphasised in the work of $\mathbf{H}$ Lubsczyk, Die Bundesurkunde: Ursprung und Wirkungsgeschichte des Deuteronomiums (Schriftenreihe der Gustav-Siewerth-Akademie 4), Weilheim-Bierbronnen 1991. He attempts to demonstrate the literary historical continuum that flows from the Decalogue - as the oldest Covenant document - to the pre-monarchic Covenant code and Urdeuterononium. Such views are of course problematic, in that they negate a strong trend in contemporary research to accord priority to the Deuteronomic (Dtn) formulation of the Decalogue in $\mathrm{Dt}$ 5. The formulation of the Decalogue in Exodus 20 must be viewed as entirely a Dtr product - cf C Dohmen, "Der Dekaloganfang und sein Urspnung", Biblica 74/2 (1993), 178; J Schreiner, "Kein anderer Gott! Bemerkungen zu Ex 34,11-26" in: "Wer ist wie du, HERR, unter den Gottern?" (Studien zur Theologie und Religionsgeschichte Israels für Otto Kaiser zum 70. Geburtstag, Hrsg. I Kottespier et. al), Göttingen 1994, 202.

29 Weinfeld, op cit, 1990, 26-32.

30 M Weinfeld, Deuteronomy and the deuteronomic school, Oxford 1972, 190243.

31 Cf H S Maine, Ancient Law: Its connection with the early history of society and its relation to modem ideas, Boston 1963. The following two quotations serve as significant articulations of Weinfeld's opinion: a) “Many institutions and practices were divorced from their ties to the sanctuary in a manner that rendered them completely secular" (Weinfeld, op cit, 1972, 233); and b) "The ancient Israelite apodictic legal code, as it finds expression in the Book of the Covenant and in the Priestly Code, bears a distinctly sacral cast... the book of Deuteronomy, on the other hand, not only lacks the ancient proclamations but also fails to provide any regulations dealing with violations of sacral law (= fas)" (Weinfeld, op cit, 1972, 240). 
32 D Daube, Studies in biblical law, New York 1969, 1-73; A S Diamond, Primitive law. Past and present, London 1971, 47-48, 89-90.

33 N Lohfink, "Opfer und Säkularisierung im Deuteronomium" in: Srudien zum Opfer und Kult in Alten Testament (Hrsg. A Schenker; FAT 3), Tübingen 1992, 15-43.

34 Crïsemann, op cit, 24; E A Speiser, "Authority and law in Mesopotamia" in: Oriental and Biblical Studies (Collected writings of E A Speiser, Edited by J J Finkelstein, \& M Greenberg), Philadelphia 1967, 313-323.

35 Beyerlin, op cit, 19-29; B S Childs, Exodus (OTL), London 1974, 454-458.

36 M Weber, Rechtssoziologie, Neuwied 1960, 134-138; Halbe, op cit, 464-467.

37 Halbe, op cit, 95-96.

38 Halbe, op cit, 97,126-127,146-147.

39 Halbe, op cit, 203-223.

40 Halbe, op cit, 223-230, 510-522.

41 Halbe, op cit, 440-450.

42 Halbe, op cit, 425-440, 451-459, advances intricate stylistic and structural arguments to demonstrate the correspondences between the parallel sections of Ex 22:20-26* and 23:1-7 and Ex 22:27-29 and 23:10-12a. The correspondences between Ex 22:30 and 23:13 are also outlined in detail.

43 Halbe, op cit, 433, 451-453, 457.

44 Halbe, op cit, 453-454.

$45 \quad$ Halbe, op cit, 454-457.

46 Haibe, op cit, 450, 477, 483.

47 Halbe, op cit, 459-464.

48 Halbe, op cit, 467-469, 472.

49 Halbe, op cit, 479-482.

$50 \quad$ Halbe, op cit, 449-450. 
$51 \quad$ Halbe, op cit, $460,472$.

52 Halbe, op cit, 452.

53 Osumi, op cit, 10.

54 Osumi, op cit, 149-182; Crūsemann, op cit, 137-138.

55 Within this redaction, Exodus 20:22b-26 serves as an introduction and Exodus 23:14-33 as a conclusion - Osumi, op cit, 20, 24-27, 183-185.

56 Osumi, op cit, 187-211.

57 Crüsemann, op cit, 215-216; Osumi, op cit, 164-167.

58 Osumi, op cit, 54-61; Cruisemann, op cit, 214-215. At the level of the second person singular redaction, Osumi, op cit, 53-70, finds a series of three tripartite units within the "Wisdom"-section, namely Ex 22:20a-23:9a*, 23:10-17* and 23:18-33bB*. Exodus 22:20a-23:9a* consists of three series of social stipulations which are found in 22:20-26*, 27-29 and 23:1-8. The present discussion cannot engage in a critique of this structural analysis.

59 Osumi, op cit, 167-174.

60 Cf J A Dearman, Property rights in the eighth-century prophets. The conflict and its background, Atlanta 1988, 18-61; B Lang, Monotheism and the prophetic minority, Sheffield 1983, 114-127; Crüsemann, op cit, 218-219.

61 Osumi, op cir, 145, 174-175.

62 For his understanding of the juridical significance of the Mishaptim as the strict mediation between the rights and duties of guilty and injured parties, see especially Crüsemann, op cit, 198. The Mishparim consistently determine the limits of legal liability, while they also establish basic principles for compensation.

63 Crisemann, op cit, 175-176,179-188.

64 Osumi, op cit, 87-145.

65 Osumi, op cit, 140-145; Crüsemann, op cit, 113-118, 195-198.

66 Crüsemann, op cit, 177, correctly criticises Osumi's limitation of the sphere of the original material in Ex 21:12-36 to cases of liability or non-liability for fatal injuries - of Osumi, op cit, 120,139. Clearly this section also deals with nonfatal bodily injuries (i.e. Ex 21:18-19,22). 
68 Osumi, op cit, 69-85, 149-155; Crüsemann, op cit, 200.

69 Cf Crūsemann, op cit, 199; Osumi, op cit, 79, 155.

70 Osumi, op cit, 153-155.

71 Crisemann, op cit, 138-170.

72 E Aurelius, Der Fürbitter Israels. Eine Studie zum Mosebild im Alten Testament (CBOTS 27), Stockholm 1988, 116-121; E Blum, Studien zur Komposition des Pentateuch (BZAW 189), Berlin 1990, 65-70, 369-375; Schreiner, op cit, 199213; E W Nicholson, God and his people. Covenant and theology in the Old Testament, Oxford 1986, 134-150; L Perlitt, Bundestheologie im Alten Testament (WMANT 36), Neukirchen-Vluyn 1969, 216-232.

73 E Zenger, Israel am Sinai. Analysen und Interpretationen zu Exodus 17-34, Altenberge 1982, 156-195.

74 Dohmen, op cit, 175-195; idem, “Der Sinaibund als neuer Bund nach Ex 1934" in: Der neue Bund im alten. Studien zur Bundestheologie der beiden Testamente (Hrsg. E Zenger; QD 146), Freiburg 1993, 58-67.

75 Cf G Robinson, The origin and development of the Old Testament Sabbath (BET 21), Frankfurt 1987, 126-138; contra Aurelius, op cit, 120-121; Blum, op cit, 69; who view Exodus 34:18-26* as a Dtr reworking of cultic prescriptions from Exodus 23:14-19. As Robinson, op cit, 131, remarks, "Sabu'ot seems to be the original... name for the feast... and basically it means a seven day unit". The different appellation of the feast in Exodus 23:14-19 may point to a loosening of the association between the rest-day and the seven day periods between the two festivals.

76 E Otto, "Saba/sabu'ot", ThWAT VIl/8 (1991), 1022-1023, comments that the Dtr redactor's purpose was to emphasize the identity of the laws on the first and second tablets (cf Ex 34:1b).

77 Blum, op cit, 365-377; cf also Childs, op cit, 454, 460-461; Otto, op cit, 1988, 58.

78 Cf Schwienhorst-Schơnberger, op cit, 234-237, 284-285, 416-417.

79 Schwienhorst-Schönberger, op cit, 417.

80 Schwienhorst-Schőnberger, op cit, 44-284.

81 Schwienhorst-Schōnberger, op cit, 269-276. 
82 Schwienhorst-Schönberger, op cir, 276-281.

83 Schwienhorst-Schönberger, op cit, 281-282.

84 Schwienhorst-Schönberger, op cit, 38-43, 235.

85 The original casuistic law book thus opened with the stipulations for cases of fatal and non-fatal bodily injuries in Ex 21:12 and 18-19, which stand in the relationship of a "case" (Fall) and its "opposite case" (Gegenfall) Schwienhorst-Schőnberger, op cit, 226-231.

86 Cf Schwienhorst-Schönberger, op cit, 231-232.

87 Schwienhorst-Schönberger, op cit, 24-25, 232.

88 Schwienhorst-Schönberger, op cir, 61-79, 99-1 28, 137-140, 175-182.

89 Schwienhorst-Schönberger, op cir, 199-205.

90 In the light of the conspicuous $6 / 7$ scheme which is shared by Exodus 21:2-11 and 23:10-12, as well as their division into two sections (Ex 21:2-6/7-11, 23:10-11/12), Schwienhorst-Schönberger, op cit, 30, argues that both units are the literary creation of this Gottesrecht redactor. In Exodus 23:10-12 an old fallow and rest-day command, which is itself literarily dependent on the oldest formulation of the rest-day command in Exodus 34:21a, was reworked.

91 On the thematic and lexical correspondences between these two units, see Schwienhorst-Schōnberger, op cit, 30-31.

92 Schwienhorst-Schönberger, op cir, 32.

93 For the discussion of Exodus 22:20-26, and the problem of the Dtr redaction in this section, see Schwienhorst-Schönberger, op cit, 331-359.

94 Schwienhorst-Schōnberger, op cit, 378-388, allocates 23:1-7 to the Gottesrecht redaction and 23:8-9 to Dtr.

95 Schwienhorst-Schönberger, op cit, 271, 279, 311-312.

96 Schwienhorst-Schönberger, op cit, 366.

97 Schwienhorst-Schסnberger, op cit, 297-298.

98 Schwienhorst-Schőnberger, op cit, 285.

99 Schwienhorst-Schönberger, op cit, 32-33. 
100 Otto, op cit, 1988, 52-53, 69-72.

101 Otto, op cit, 1988, 4-6, 57-60.

102 Otto, op cit, 1988, 66-68.

103 The procedural law in Exodus 23:1-8 accentuates the differentiation of the individual from the collective legal community - cf Otto, op cit, 1988, 47.

104 Otto, op cit, 1988, 61-66; idem, "Interdependenzen zwischen Geschichte und Rechtsgechichte des antiken Israels", Rechtshistorisches Journal 7 (1988), 356362.

105 Otto's assessment of the social conditions which precipitated the shift from law to ethos is similar to the arguments which have already been noted in the works of Osumi and Schwienhorst-Schönberger. See Otto, Rechtshistorisches Journal 7 (1988), 360-364; op cit, 1988, $41-44$.

106 Otto, op cit, 1988, 35-37.

107 Otto, Rechtshistorisches Journal 7 (1988), 365.

108 Otto, op cit, 1988, 38-40; Rechtshistorisches Journal 7 (1988), 363.

109 Otto, op cit, 1988, 39 refers especially to the words (22:24a) and จบา (25a) to illustrate the social solidarity which is invoked within 22:20 $26 *$.

110 Otto, op cit, 1988, 38-40.

111 For an outline of the redactional arrangement of each major section, see Otto, op cit, 1988, 9-10.

112 Otto, op cit, 1988, 35-37.

113 Otto, op cit, 1988, 40-44.

114 Otto, op cit, 1988, 49-51.

115 Otto, Rechtshistorisches Joumal 7 (1988), 364.

116 Otto, op cit, 1988, 52-53.

117 The title of the paper is "The pre-exilic Deuteronomy as a revision of the Covenant Code". 
118 Cf Otto, op cit, 1988, 40; S Lach, “La sens de l'attribut de dieu Hannun* $₫$ la lumière des Psaumes", Folia Orientalia 21 (1980), 98-102.

119 Cf Aurelius, op cit, 116-117; H Spieckermann, "Barmherzig und gnådig ist der Herr...", ZAW 102/1 (1990), 1-2.

120 Spieckermann, ZAW 102/1 (1990), 3.

121 E Otto, "Kultus und Ethos in Jerusalemer Theologie. Ein beitrag zur theologischen Begñndung der Ethik im Alten Testament", ZAW 98 (1986), 161-179.

122 Cf H J Kraus, Psalmen 1-59 (BKAT 15/1), Neukirchen 1978, 254; idem, "Tore der Gerechtigkeit" in: Ernten, was man sät (Festschrift für Klaus Koch zu seinem 65. Geburtstag, Hrsg. D R Daniels, U GleBmer, \& M Rösel), Neukirchen-Vluyn 1991, 266.

123 Cf J Jeremias, Das Konigtum Gottes in den Psalmen: Israels Begegnung mit dem kanaanaischen Mythos in den Jahwe-Konig Psalmen (FRLANT 141), Gōttingen 1987; B Janowski, "Das Königtum Gottes in den Psalmen. Bemerkungen zu einem neuen Gesamtentwurf", ZThK 86 (1989), 389-454.

124 B Janowski, Rettungsgewißheit und Epiphanie des Heils. Das Motiv der Hilfe Gottes "am Morgen" im Alten Orient und im Alten Testament. Band 1: Alter Orient (WMANT 59), Neukirchen-Vluyn 1989.

125 O Keel, "Fern von Jerusalem. Frühe Jerusalemer Kulttraditionen und ihre Trăger und Trägerinnen" in: Zion. Ort der Begegnung. (Festschrift für Laurentius Klein zur Vollendung des 65. Lebensjahres, Hrsg. F Hahn et. al; BBB 90), Bodenheim 1993, 439-502.

126 H-P Stăhli, Solare elemente im Jahweglauben des Alten Testaments (OBO 66), Freiburg 1985.

127 Stähli, op cit, 10-11; S Schroer, In Israel gab es Bilder. Nachrichten von darstellender Kunst im Alten Testament (OBO 74), Freiburg 1987, 297-299.

128 Schroer, op cit, 297; M S Smith, "The near Eastern background of solar language for Yahweh", JBL 109/1 (1990), 31-32.

129 Schwienhorst-Schönberger, op cir, 21. 